\title{
Effect of Maize Stover Compost and Nitrogen Fertilizer Rates on Growth and Yield of Soyabean (Glycine Max) Variety in South - West Nigeria
}

\author{
Adeyeye A.S, Togun, A. O., Akanbi W. B., Adepoju,I. O., Ibirinde,D. O. \\ Federal University, Wukari Taraba State. Nigeria. \\ University of Ibadan, Ibadan, Oyo State, Nigeria. \\ Ladoke Akintola University of Technology, Ogbomoso. Oyo State. Nigeria.
}

\begin{abstract}
The study investigated the influence of maize - Stover compost and $N$-fertilizer rates on the growth, yield and utilization soybean over a period of two years. The experimental design was a randomized complete block $(R C B D)$, consisting 3 levels of compost $(0,2,4 t / h a), 3$ rates of $N$ fertilizer $(0,30,60 \mathrm{~kg} / \mathrm{ha})$ which were applied to 3 varieties of soybean (TGX $1742-2 F)$, (TG x1842- 1 E) and (TG $x$ 1448-2E) using three replications. Data analysis using ANOVA at 5\% level of probability showed the application of maize Stover compost and $N$-fertilizer to have enhanced plant growth significantly( Plant height, number of leaves, node, and branches,). Dry matter yield and number of pods per plant were also significantly affected by the different levels of compost and $\mathrm{N}$ - fertilizer rates. The results of the soybean grain yield and yield components showed that the crop responded positively to the application of both compost and $N$-fertilizer, but soybean response to compost fertilizer was higher than that of $N$-fertilizer. The highest seed number per plant of $(160.9 \mathrm{~g})$ was produced by variety TGX 1740- $2 F$ while the highest numbers of pods were produced from the application rate of 2 and 4 tha compost. Application rate of 4 t/ha compost produced the highest number of seed per plant of (154. $4 \mathrm{~g}$ ).The optimum performance of soybean grain was obtained from application of 2 or 4 tha of compost. Key words: Soybean variety, Compost, Nitrogen rates
\end{abstract}

\section{Introduction}

Soya bean (Glycine $\max (\mathrm{L})$ merr, is an important grain legume in Nigeria and one of the world most valued oil seed crops. (Ogudipe et al, 1989, Adeyeye 2009). The crop has been described as the world's chief source of edible vegetable oil and high protein feed for livestock which compares favorably with animal protein source containing all the essential amino acid required by man (Manual and Saxena 2003). The present emphasis on consumption and utilization of soybean in Nigeria will no doubt step up both domestic and industrial demand. (IITA, 1990). One of the major problems associated with soybean production in the tropical ecology is poor soil fertility. This is due to the intensive cropping system which has now become a characteristic feature of Nigerian's arable agriculture. The way forward could be linked to the use of fertilizer (inorganic or organic sources). The plant growth and development are improved when nitrogen in form of ammonium (N H4 ${ }^{+}$) or nitrates $\left(\mathrm{NO}_{3}\right)$ are added into the soil from either inorganic or organic sources at certain growth phase of the crop .The use of chemical fertilizer has drastically reduced due to scarcity and high price (Akanbi et al 2001, Daramola, et al 2009). Hence most developing countries are now exploring the value of organic fertilizers (Babatola et al, 2002). In addition complementary use of organic manure and minerals fertilizer has also been practiced in the tropics and high and sustained crops yield can be obtained with judicious and balanced $\mathrm{N}-$ fertilization combine with organic matter amendment (Mankinde et al 2001).The aim of the study is to evaluate the effect of compost and nitrogen fertilizer on the growth and grain yield of soybean in south west Nigeria.

\section{Materials And Methods}

Field experiments ( $3^{3}$ factorial designs) were conducted on an experimental plot at Apete, Ibadan for two years. Pre cropping soil sample of the trial site were chemically analyzed and the result are presented in table 1.

\section{COMPOST PREPARATION}

The compost was made from maize Stover and well cured poultry manure. The Stover were collected from early season maize, and air-dried and chopped into particle size of $(5 \mathrm{~mm})$ with chaff cutter. The materials were combined in ratio 3:1 of maize Stover and poultry manure by weight and both were composted in concrete pit. The compost heap were watered and turned once a week for the first three weeks and fortnightly for six weeks the temperature and $\mathrm{pH}$ of the heap were monitored weekly till maturity. At maturity the compost were evacuated air dried and shredded to pass through a $3.2 \mathrm{~mm}$ sieve. Samples were randomly taken for chemical nutrient analysis. The result is presented in table 2 . 


\section{TREATMENTS AND EXPERIMENTAL DESIGN}

The treatments consisted of three levels of compost $(0,2$ and $4 \mathrm{t} / \mathrm{ha})$ and three level is of nitrogen fertilizers $(0,30$, and $60 \mathrm{kgN} / \mathrm{ha}$ ) which were applied to three varieties of soybean (TGx $1742-2 \mathrm{~F})$, (Tx1842$1 \mathrm{E})$ and (TGx1448-2E). The factorial combination of the 3 treatments levels resulted in 27 different treatments. The $\mathrm{N}$ fertilizer used was urea which has $45 \% \mathrm{~N}$ in $50 \mathrm{~kg}$ bag. The compost treatments were uniformly applied to the plot and worked into the soil by high hoeing a week before transplanting while $\mathrm{N}$ fertilizer were applied at two week after planting.

The experimental design factional were arranged in randomized complete block design with three replication.Weeding was done manually at two weeks after planting and as at when necessary while insect pest was controlled through the application of karate at the rate of $2 \mathrm{ml} /$ litre. Spraying started two weeks after planting and fortnightly till pod formation.

Data were collected on plant height, number of leaves, number of branches, number of node and grain yield. Dry yield analysis was carried out by uprooting three plants per plot at 2, 4, 6,8,10, and 12 weeks after planting and divided into root, stem, leaves, flowers and pods oven dried at $80^{\circ \mathrm{c}}$ to

Constant weight. Analyses of the data collected were carried out using (ANOVA) at 5\% level of probability where the separated mean were subjected to Duncan Multiple Range Test.

\section{Results}

The effects of variety, different levels of compost and $\mathrm{N}$ - fertilizer on the growth parameters of soybean are shown in figures( 1-4).Variety effect was significant on the number of leaves and at 8 weeks after planting variety TGx1842 - IE had the significantly highest number of leaves. Also on the height of the plants, number of nodes per plant and branches, same trend was observed where TGx 1842- IE, was superior to other varieties. (fig,1). Compost application rates have significant effects on number of leaves, plant height, number of nodes and branches per plant. At 10 weeks after planting, 2t/ha compost rate produced plants with the highest number of leaves per plants followed by $4 \mathrm{t} / \mathrm{ha}$ compost. At 8 and $12 \mathrm{WAP}$, compost rate of $4 \mathrm{t} / \mathrm{ha}$ produced the tallest plant which was not significantly different from $2 \mathrm{t} / \mathrm{ha}$ compost rate application. This was also the trend with numbers of nodes and branches. Application of $\mathrm{N}$ - fertilizer had no significant effect on all the growth parameter studied, but there general improvement in crop performance with the application of 30 , and $60 \mathrm{~kg}$ $\mathrm{N} / \mathrm{ha}$ fertilizer over non fertilized plants. (fig,2)

There was a significantly varieties effect on the number of flowers at 6 and 8 weeks after planting where variety TGx 14 48-2E produced highest number of flowers. Also application of $\mathrm{N}$ fertilizer produced significantly effect on soybean number of flowers at 6 WAP where the number increases with $\mathrm{N}$ fertilizer rate up to $60 \mathrm{kgN} / \mathrm{ha} .($ fig, 3)

\section{DRY MATTER YIELD}

The varietals effect was significant on dry matter yield of leaves, stem, flowers, Roots and pods in this study (table 3). At 10 weeks after planting, TGx1448-2E had significantly higher leaf dry weight of 4.0g/plant while TGx 1842 - 1E had the significantly highest stem dry matter at 8,10, and 12weeks after planting. The same trend was observed with root dry weight and pod dry weight where TGx1842 -1E had significantly higher root dry matter weight of $2.2 \mathrm{~g} / \mathrm{plant}$ and $19.7 \mathrm{~g} / \mathrm{plant}$ respectively. But TGx1448- $2 \mathrm{E}$ had the highest flower dry weight when compared with other varieties.(fig,4)

Compost application had no significant effect on the leaf dry weight and flower dry weight at all sampling times. But there was a significant effect of compost application on stem dry weight, root dry weight, and pod dry weight. Where compost rates of 2 and $4 \mathrm{t} /$ ha gave similar results. $\mathrm{N}$ - Fertilizer produced no significant effects on leaves dry weight, root dry weight and flower dry weight. But there was a significant effect of $\mathrm{N}$-fertilizer on stem dry matter weight only at 6 week after planting and at 12 weeks after planting for pod dry weight where 30 and $60 \mathrm{kgN} /$ ha were not significantly different.(table,4)

\section{YIELD PARAMETERS}

Varietal effect was significant on the yield parameters, such as numbers of pods, number of seeds, seed weight and grain yield. At 12 weeks after planting variety TGx 1842 -1E produced significantly highest number of pods per plant, while variety TGx1740 - 2F had significantly higher number of seed per plants and seed weight per plant .Soybean variety TGx1740 - 2F also produced the highest grain yield when compared with other varieties in the study.(table,5)

Compost application rates produced a significant effect on all the yield parameter, with 2 and $4 \mathrm{t} / \mathrm{ha}$ producing similar results which are higher than what was observed with no compost. $\mathrm{N}$-fertilizer rates were also significant where rate of 30 and $60 \mathrm{kgN} / \mathrm{ha}$ fertilizer were not significantly different.(fig,5) 


\section{Discussion}

The application of maize Stover compost and $\mathrm{N}$ - fertilizer enhanced plant growth and development. This underscores the necessity for $\mathrm{N}$ - nutrition during early growth of soybean. The variety TGx 1842-1E in most cases had higher responses to compost and $\mathrm{N}$ fertilizer application when compared with other varieties. This could be due to its genetics superiority over the others (Eteborn, 1987, Adeyeye, 2009).

Although application of compost and $\mathrm{N}$-fertilizer improved crop performance but soybean responses to $\mathrm{N}$ - fertilizer alone was very low on most parameters taken. This may be due to initial soil N- level of $0.01 \mathrm{~g} / \mathrm{kg}$ or high loss through leaching of the applied $\mathrm{N}$ - which may be due to nature of the soil used for the study coupled with high rain fall during experiment. Application of compost had significant effect on development of soybean vegetative parameters. The number of leaves, stem height, number of nodes and branch number per plant increased significantly from 0t/ha to $4 \mathrm{t} / \mathrm{ha}$ compost with irrespective of the growth stages which agree by the experimental result of Bittenbender et al (1998) and Akanbi and Togun (2002) on amaranth. They reported significant reduction in plant growth parameters when soil is deficient in nutrients especially $\mathrm{N}$. The higher plant growth as a result of compost application may be associated with the fact that compost release though in a slowly rate considerable amount of nutrients for plant uses which is essential for formation of plant molecules such as chlorophyll and protoplasm formation (Robert and Andrew, 1989). The capability of organic compost to improve soil structure, retain nutrients and water for plant use could also partly explain the observed result (Lai 1987). Application of 4t/ha, compost gave the highest pod weight and grain yield which is similar to $2 t /$ ha compost rate, which may be due to higher nutrient uptake with higher rates of fertilizers which facilities more photosynthetic activity and more partitioning on dry matter into pods and seeds (Gungula, 1999, Akabi 2002).

\section{Conclusion}

The response of soybean in terms of increased plant vegetative growth, dry matter weight and grain yield to applied compost in this study indicates essentiality of nitrogen nutrition as a starter for optimum soybean productivity especially when supplied at the rate of 2 to $4 \mathrm{t} / \mathrm{ha}$ composts which showed promises as organic $\mathrm{N}$ sources over the inorganic fertilizer used in terms of enhancement in the value of almost all the variable evaluated.

\section{References}

[1]. Adeyeye A.S (2009). Pod shattering attributes and response of soybean (Glyeine max(L) Merrill) to compost, Nitrogen fertilizer and rhizobium inoculation. Ph.D Thesis in the dept. of crop protection and environmental Biology, University of Ibadan. Nigeria.

[2]. Akanbi W.B (2002) Growth, nutrient uptake and yield of maize and okra as influence by compost and nitrogen fertilizer under different cropping systems. Ph.D thesis in the department of crop protection and Environmental Biology University of Ibadan. Nigeria.

[3]. Akanb W.B, and Togun. A.O. (2002). The influence of maize Stover compost and nitrogen fertilizer on growth, yield and nutrient uptake of Amaranth Scientia Horticulture (93): 1-8 (E/SEVIE R uk)

[4]. Babatola, L.A, and Olaniyi. J.O. (1997). Effect of NPK fertilizer levels and plant spacing on performance and shelf life of Okra. Nig. J. plant protection 13: 23-29.

[5]. Bitten bender, H.C, Hue, N.V, Kent F and Hilary, B, (1998). Sustainability of organic fertilization macadamia with macadamia husk- manure compost. Commun soil sci. plant Anal 29 (3\&4): 409-419.

[6]. Daramola, D.S, Adeyeye, A.S and lawal, D. (2009) Effect pf application organic and inorganic nitrogen fertilizers on the growth and dry matter yield of Amaranthus crentus. Acta satech vol 3: (1) : 1- 6.

[7]. Etebom, S.A (1987). Inheritance of pod shattering and its relationship with some agronomic characterizes in soyabean (Glycine maxi (L) Merrill). M.SC. thesis in the Department of plant science, Faculty of Agriculture A.B.U, Zaria, Nigeria.

[8]. Gungula, D.T. (1999). Growth and nitrogen use efficiency in maize (Zea mays L.) in the Southern Guinea Savanna of Nigeria Ph.D Thesis, university of Ibadan $181 \mathrm{PP}$.

[9]. IITA, (1990): Annual report for 1989/90.Internation Institute of Tropical Agriculture, OYO Road, Ibadan Nigeria PP 53-59.

[10]. Manral, H.S, and Saxena, S. C (2003). Plant growth, yield Attributes and grain application of inorganic and organic sources of nutrients. ENvis Bulletin Vol 8 no 1, PP 1-4

[11]. Ogundipe, H.O, Dashiell, K.E, and Osho, S.M (1989) soymilk yield and quality as affected by soybean varieties and processing technique. Tropical Legume Bulletin 38.

[12]. Makinde. E.A, Anoola, O.T, and Akande, M.O, 2007. Effect of oregano-mineral fertilizer application on the growth and yield of 'Egusi' melon. Australian Journal of Basic and applied sciences (1): 15 - 19.

Table 1: Pre cropping soil chemical and physical analysis of experimental soil Properties

$\begin{array}{lc}\mathrm{pH}(\mathrm{H} 20) & 6.2 \\ \text { Organic Carbon }(\%) & 0.14 \\ \text { Total N (\%) } & 0.01 \\ \text { Available P (ppm) } & 0.87 \\ \mathrm{Fe}(\mathrm{mg} / \mathrm{kg}) & 6.00\end{array}$




$\begin{array}{lc}\mathrm{Cu}(\mathrm{mg} / \mathrm{kg}) & 0.70 \\ \mathrm{Zn}(\mathrm{mg} / \mathrm{kg}) & 2.10 \\ \text { Exchangeable K }(\mathrm{c} \mathrm{mol} / \mathrm{kg}) & 0.34 \\ \text { Exchangeable } \mathrm{Na}(\mathrm{c} \mathrm{mol} / \mathrm{kg}) & \\ \text { Exchangeable } \mathrm{Ca}(\mathrm{c} \mathrm{mol} / \mathrm{kg}) & 0.43 \\ \text { Exchangeable } \mathrm{Mg}(\mathrm{c} \mathrm{mol} / \mathrm{kg}) & 0.04 \\ \text { Exchangeable Acidity }(\mathrm{c} \mathrm{mol} / \mathrm{kg}) & \\ \text { E C E C }(\mathrm{c} \mathrm{mol} / \mathrm{kg}) & 0.81 \\ \text { Base saturation }(\mathrm{g} / \mathrm{kg}) & 930 \\ \text { Sand }(\mathrm{g} / \mathrm{kg}) & 840 \\ \mathrm{Silt}(\mathrm{g} / \mathrm{kg}) & 147 \\ \text { Clay }(\mathrm{g} / \mathrm{kg}) & 11 \\ \end{array}$

Textural Class; $\quad$ Loam sand

Table 2: Chemical properties of Compost materials and matured compost

\begin{tabular}{lccc}
\hline Properties & Maize Stover & Poultry manure & Matured compost \\
\hline$\% \mathrm{~N}$ & & & 16.60 \\
$\% \mathrm{P}$ & 0.80 & 1.82 & 10.20 \\
$\% \mathrm{~K}$ & 0.11 & 2.25 & 1.82 \\
$\% \mathrm{Ca}$ & 1.15 & 0.72 & 2.80 \\
$\% \mathrm{Mg}$ & 1.08 & 5.25 & 0.56 \\
$\% \mathrm{Fe}$ & 0.58 & 0.61 & 320.80 \\
$\% \mathrm{Zn}$ & 485.0 & 455.00 & 98.50 \\
$\% \mathrm{Cu}$ & 90.00 & 105.50 & 16.80 \\
\hline
\end{tabular}
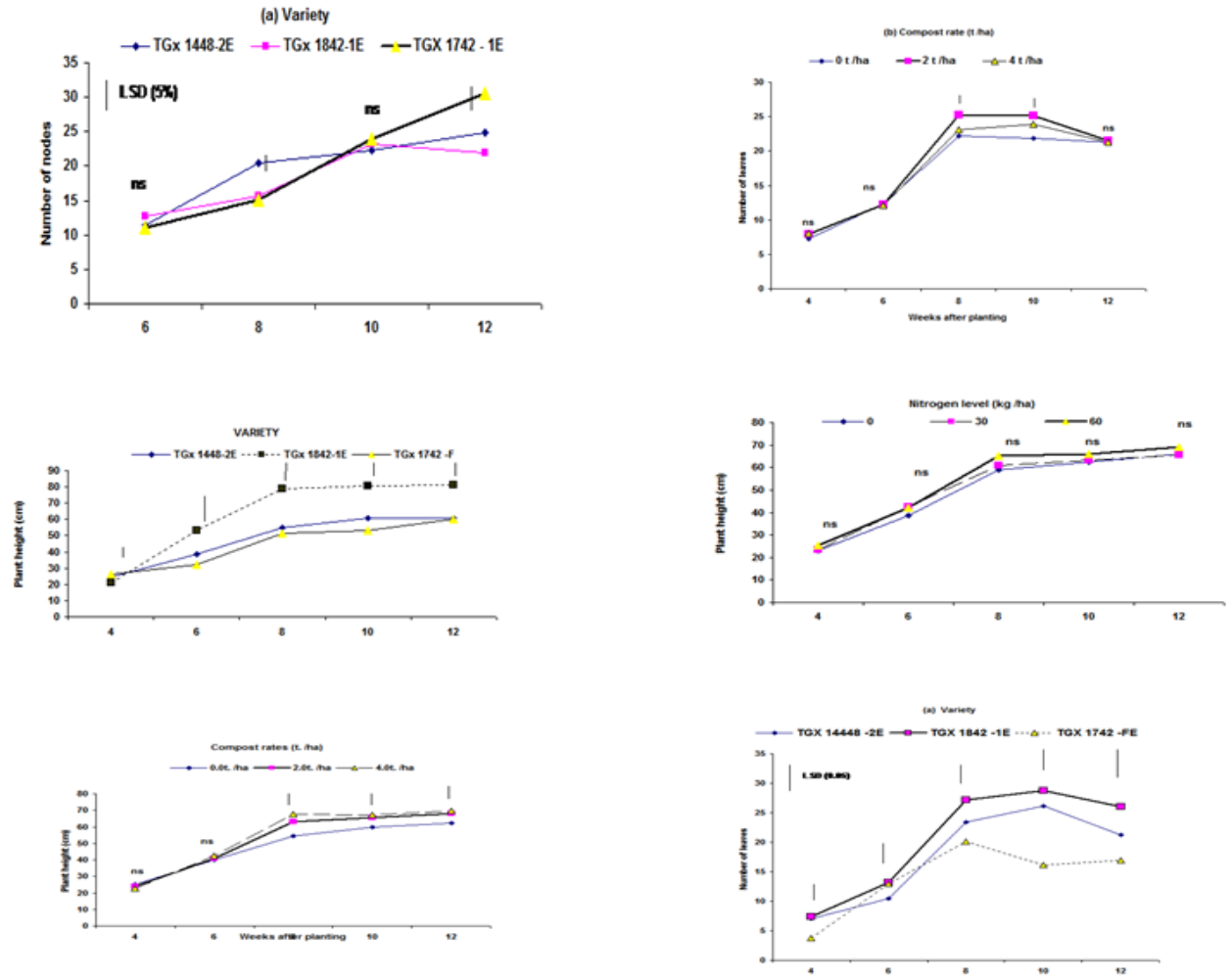

Fig. 1: Effects of (a) variety and (b) compost rate on soyabean number of leaves at different growth stages at Ibadan 

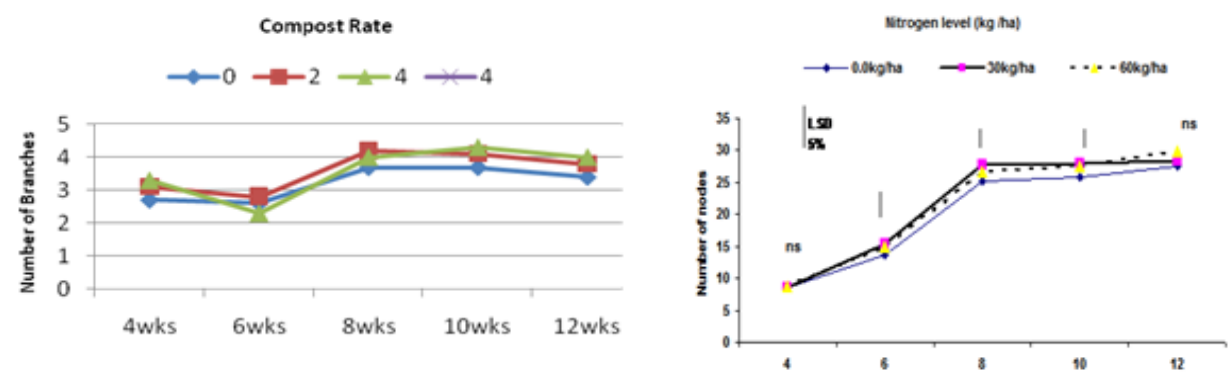

Variety
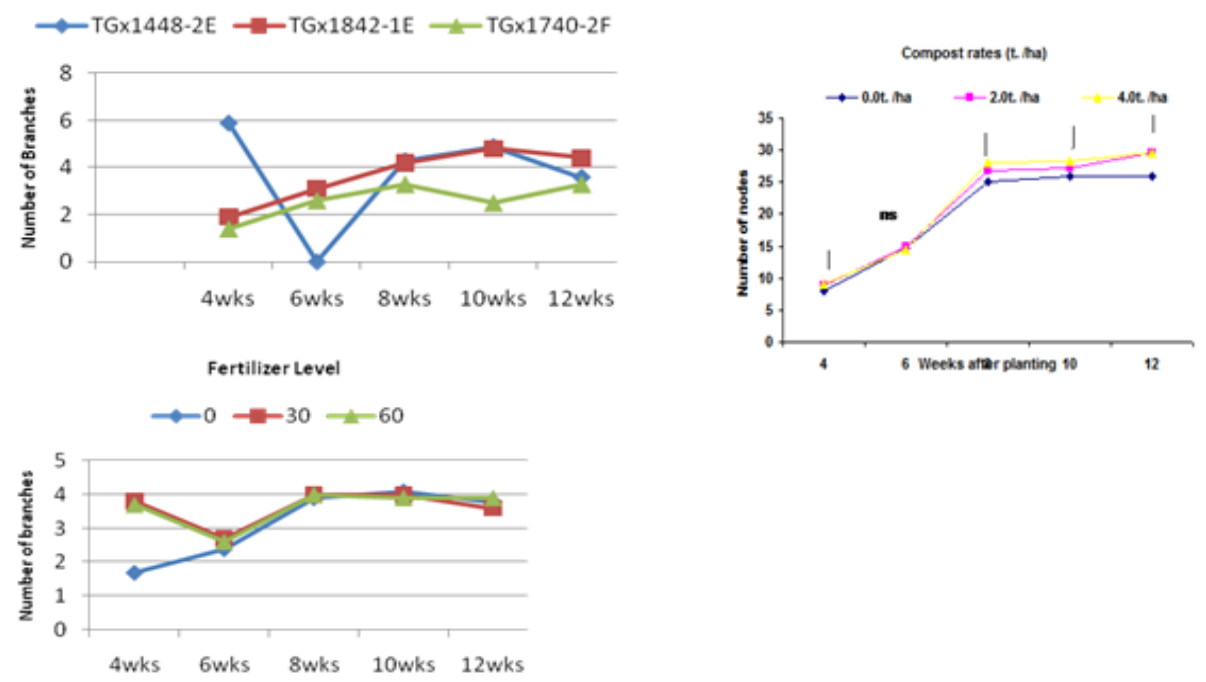

FIg: 2. Effect of Variety, Nitrogen and Compost on soyabean number of branches and node at different growth stages.
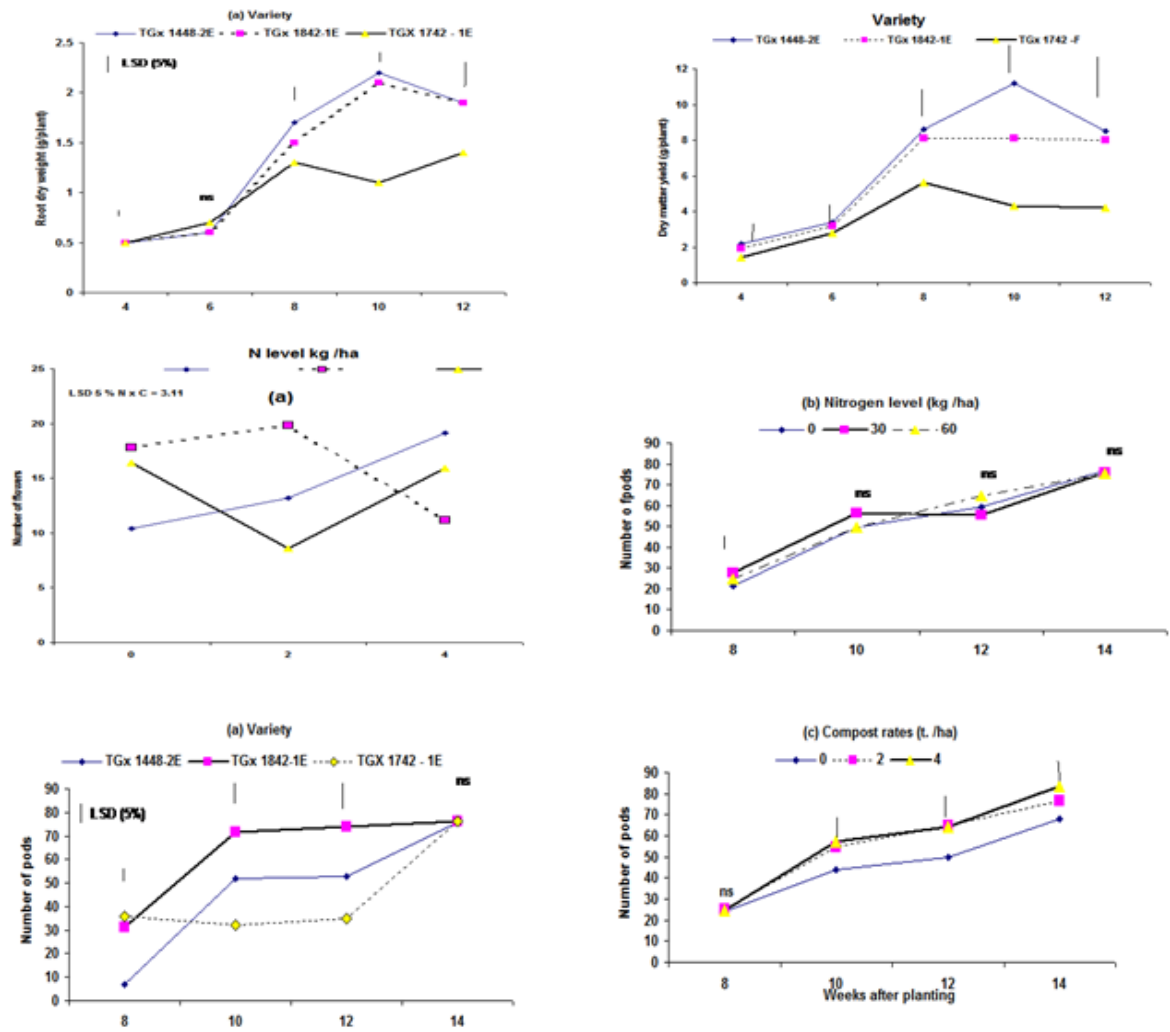

Fig: 3.Effect of Variety, Nitrogen and Compost on soybean root dry weight, number of flower, dry mater yield and number of pods at different growth stages. 
Table 3: Main Effects of variety, fertilizer and compost on soyabean stem dry weight (g /plant) at different ages .

\begin{tabular}{|c|c|c|c|c|c|}
\hline \multirow[t]{2}{*}{ Treatment } & \multicolumn{3}{|c|}{ Weeks after planting } & \multirow[b]{2}{*}{10} & \multirow[b]{2}{*}{12} \\
\hline & 4 & 6 & 8 & & \\
\hline \multicolumn{6}{|l|}{ Variety } \\
\hline TGx 1448-2E & 0.8 & 1.9 & 5.1 & 7.4 & 6.1 \\
\hline TGx 1842-1E & 0.7 & 1.4 & 5.8 & 7.1 & 7.6 \\
\hline TGx 1740-2F & 0.7 & 1.5 & 4.1 & 2.7 & 4.2 \\
\hline Prob. of F & ns & $* *$ & $* *$ & $* *$ & $* *$ \\
\hline $\operatorname{LSD}(5 \%)$ & 0.14 & 0.28 & 0.92 & 1.09 & 1.03 \\
\hline \multicolumn{6}{|c|}{ Fertilizer level (kg / ha) } \\
\hline 0 & 0.7 & 1.4 & 4.9 & 5.3 & 5.7 \\
\hline 30 & 0.7 & 1.8 & 5.0 & 6.1 & 6.3 \\
\hline 60 & 0.7 & 1.7 & 5.1 & 5.8 & 6.0 \\
\hline Prob. of F. & ns & $*$ & ns & Ns & Ns \\
\hline $\operatorname{LSD}(5 \%)$ & 0.14 & 0.28 & 0.92 & 1.09 & 1.03 \\
\hline \multicolumn{6}{|c|}{ Compost rate (t. /ha) } \\
\hline 0 & 0.6 & 1.6 & 4.5 & 5.5 & 5.7 \\
\hline 2 & 0.7 & 1.6 & 5.0 & 5.9 & 5.6 \\
\hline 4 & 0.8 & 1.7 & 5.5 & 5.7 & 6.7 \\
\hline Prob. of F. & $*$ & Ns & $*$ & Ns & $*$ \\
\hline $\operatorname{LSD}(5 \%)$ & 0.14 & 0.28 & 0.92 & 1.09 & 1.03 \\
\hline
\end{tabular}

$*, * *=$ Significant at 5 and $1 \%$ probability levels respectively; ns $=$ not significant at $5 \%$ probability level.

Table 4: Main Effect of variety, fertilizer and compost on soyabean flower and pod dry weight (g) at different ages .

\begin{tabular}{|c|c|c|c|c|c|}
\hline \multirow[t]{3}{*}{ Treatment } & \multicolumn{2}{|c|}{ Flower dry weight (g. /plant) } & \multicolumn{2}{|c|}{ Pod dry weight (g. /plant) } & \\
\hline & \multirow[b]{2}{*}{4} & \multicolumn{2}{|c|}{ Weeks after planting } & \multirow[b]{2}{*}{12} & \\
\hline & & 6 & 8 & & \\
\hline Variety & & & & & \\
\hline TGx 1448-2E & 0.6 & 0.2 & 0.2 & 2.7 & 9.7 \\
\hline TGx 1842-1E & 0.1 & 0.1 & 1.1 & 7.1 & 19.7 \\
\hline TGx $1740-2 F$ & 0.1 & 0.1 & 2.3 & 4.3 & 17.6 \\
\hline Prob. of $F$ & $* *$ & $* *$ & $* *$ & $* *$ & ** \\
\hline $\operatorname{LSD}(5 \%)$ & 0.39 & 0.05 & 0.28 & 0.95 & 2.82 \\
\hline Fertilizer leve & & & & & \\
\hline 0 & 0.6 & 0.1 & 1.1 & 4.2 & 14.4 \\
\hline 30 & 0.1 & 0.1 & 1.3 & 5.2 & 14.3 \\
\hline 60 & 0.1 & 0.1 & 1.1 & 4.7 & 18.4 \\
\hline Prob. of F. & $* *$ & Ns & ns & Ns & ** \\
\hline $\operatorname{LSD}(5 \%)$ & 0.34 & 0.05 & 0.28 & 0.95 & 2.82 \\
\hline Compost rate & & & & & \\
\hline 0 & 0.1 & 0.1 & 1.1 & 3.7 & 13.0 \\
\hline 2 & 0.1 & 0.1 & 1.1 & 5.3 & 15.8 \\
\hline 4 & 0.4 & 0.1 & 1.3 & 5.1 & 18.2 \\
\hline Prob. of $\mathrm{F}$. & ns & Ns & Ns & $* *$ & $* *$ \\
\hline $\operatorname{LSD}(5 \%)$ & 0.39 & 0.05 & 0.28 & 0.95 & 2.82 \\
\hline
\end{tabular}

$*, * *=$ Significant at 5 and $1 \%$ probability levels respectively $\mathrm{ns}=$ not significant at $5 \%$ probability level. 

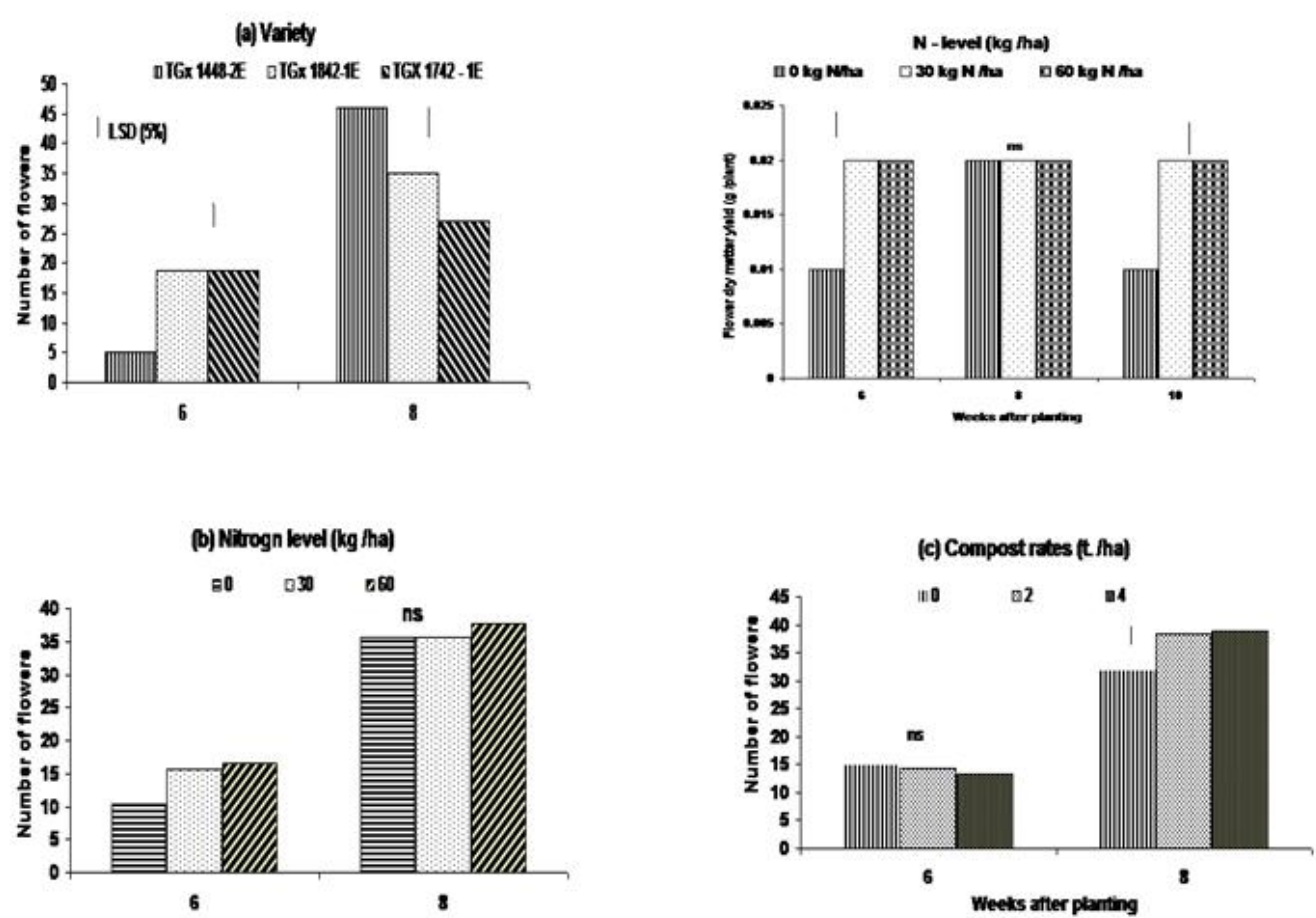

Fig 4: Effect of Variety, Nitrogen and Compost on soybean number of flower and flower dry weight at different growth stage.

Table 5: Main effects of variety, fertilizer and compost on soyabean seed attributes at final harvest (14 WAP).

\begin{tabular}{|c|c|c|c|c|}
\hline Treatment & $\begin{array}{l}\text { Number of seed } \\
\text { /plant }\end{array}$ & $\begin{array}{l}\text { Seed weight } \\
\text { / plant }(g)\end{array}$ & $\begin{array}{l}\text { Husk weight } \\
\text { (g. /plant) }\end{array}$ & Seed: husk ratio \\
\hline \multicolumn{5}{|l|}{ Variety } \\
\hline TGx $1448-2 \mathrm{E}$ & 123.8 & 27.0 & 9.0 & $3: 1$ \\
\hline TGx 1842-1E & 132.4 & 27.0 & 9.3 & $3.2: 1$ \\
\hline TGx $1740-2 \mathrm{~F}$ & 160.9 & 30.0 & 7.5 & $4: 1$ \\
\hline Prob. F & $* *$ & $* *$ & Ns & $* *$ \\
\hline $\operatorname{LSD}(5 \%)$ & 24.18 & 2.61 & 1.71 & $1.5: 1$ \\
\hline \multicolumn{5}{|c|}{ Nitrogen level (kg. /ha) } \\
\hline 0 & 147.1 & 22.0 & 7.2 & $3.1: 1$ \\
\hline 30 & 141.7 & 25.0 & 9.6 & $2.6: 1$ \\
\hline 60 & 128.3 & 27.0 & 9.3 & $2.0: 1$ \\
\hline Prob. of $\mathrm{F}$ & Ns & Ns & $*$ & $* *$ \\
\hline $\operatorname{LSD}(5 \%)$ & 24.18 & 6.03 & 1.71 & $3.5: 1$ \\
\hline \multicolumn{5}{|c|}{ Compost rate (t. /ha) } \\
\hline 0 & 120.3 & 20.0 & 6.6 & $3.0: 1$ \\
\hline 2 & 142.3 & 26.0 & 9.3 & $2.8: 1$ \\
\hline 4 & 154.4 & 29.0 & 9.9 & $2.9: 1$ \\
\hline Prob. of $\mathrm{F}$ & $*$ & $* *$ & ** & $*$ \\
\hline $\operatorname{LSD}(5 \%)$ & 24.18 & 6.3 & 1.71 & $3.7: 1$ \\
\hline
\end{tabular}
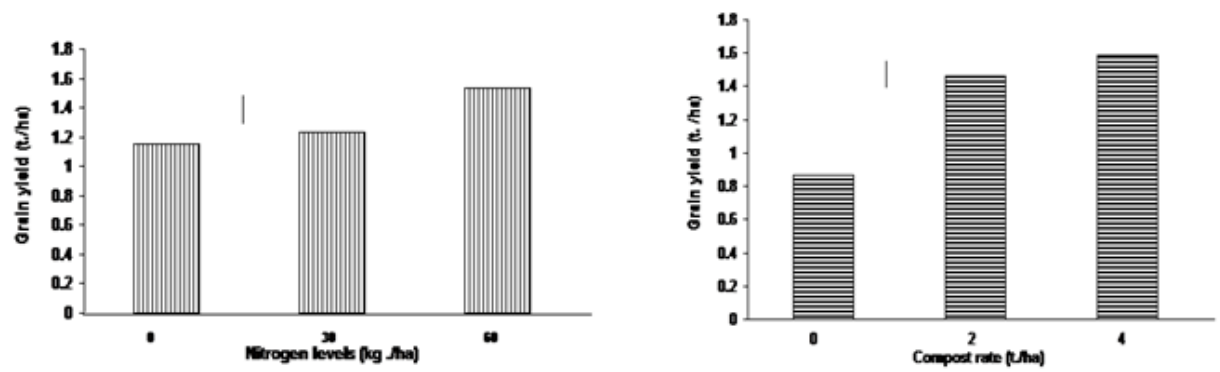

Fig 5: Effect of applied compost and $\mathrm{N}$-fertilizer on soyabean grain yield at harvest. 